\title{
Evaluation of a New Industrial Process Flow and Ergonomic Methods to Increase the Productivity and Quality in an Agricultural Industry of Mexicali Valley, Mexico
}

Yanet Villarreal González ${ }^{*}$, Pedro Alberto Escárcega Zepeda ${ }^{2}$, Carlos Raul Navarro González ${ }^{3}$, Ana Laura Sanchez Corona ${ }^{3}$, Rigoberto Zamora Alarcon ${ }^{3} \&$ Gustavo López Badilla ${ }^{4}$

${ }^{I}$ Departamento de Metalmecánica, Tecnológico Nacional de México, Instituto Tecnológico de Mexicali, Mexicali, México. ${ }^{2}$ Departamento de Ingeniería Metalmecánica-Industrial, Tecnológico Nacional de México, Instituto Tecnológico de Mexicali, Mexicali, Baja California, México. ${ }^{3}$ Departamento de Ingeniería Industrial, Universidad Autónoma de Baja California, Mexicali, Baja California, México. ${ }^{4}$ UNEA Universidad, Mexicali, Baja California, México. Corresponding author: mcvillarrealy5@hotmail.com*

Copyright: (02021 Yanet Villarreal González et al. This is an open access article distributed under the terms of the Creative Commons Attribution License, which permits unrestricted use, distribution, and reproduction in any medium, provided the original author and source are credited.

\section{ABSTRACT}

An investigation was developed to evaluate the efficiency of a new proposal method called G-shaped flow, in an agricultural industry located in the Mexicali Valley, which belongs to the city of Mexicali and is located in the northwest of the Mexican Republic, bordering the United States, in the state of California. Also, was analyzed some ergonomic methods to improve the manufacturing processes and avoid certain health problematic situation in workers of industrial processes. Productivity and quality evaluations were also elaborated, where before carrying out the investigation, levels of these manufacturing parameters were presented, close to $65 \%$ each, when the goal was $90 \%$. In this investigation was analyzed the productivity and quality of one fruit and one vegetable, and the delivery time, cultured, stored and packed in the an agricultural industry of the Mexicali Valley evaluated. In this analysis was evaluated the principal five logistic tool to be used (1) space organization system, (2) route device, (3) supply chain analysis, (4) performance evaluation and (5) continuous monitoring; to optimize the flow of the agricultural products evaluated. This was necessary because sometimes the products commercialized in this industry, due to the extreme climate in this desert area, both the minimum temperatures of up to close to $0^{\circ} \mathrm{C}$ in the winter and higher than $40^{\circ} \mathrm{C}$ in the summer, quickly generated deteriorated products that were considered as unfit products for its commercialization. The novel method as $G$ flow was very compatible to reduce the delivery time in this type of industry, saving costs by agricultural products deteriorated, avoiding financial compensation to customers to late delivery to customer and increasing the productivity and quality to get more customers. In this investigation was observed that with the three principal distribution flow as lineal, $U$ and $T$ flows; not was compatible to this type of industry, because generated a lot errors of flow and ith this the deteriorated farm products and the late delivery to customers. More than 50\% of farm products were deteriorated and for this reason was designed and used the G flow to saving costs. The investigation included an evaluation of ergonomics methods, to avoid incorrect postures that would generate discomfort or pain for the workers of this evaluated company, when they elaborated the quality inspection to separate deteriorated and good quality agricultural products, in addition to analyzing the postures at the moment packing and loading the boxes of agricultural products that this industry sells in this region and imports into the United States. This study was from 2018 to 2019.

Keywords: Agricultural industry, Logistics, G flows, Saving costs, Ergonomic methods.

\section{Introduction}

The investigation contributed to save costs in an agricultural industry installed in the Mexicali Valley and located in the northwest of the Mexican Republic. The managers and supervisor people of this industry evaluated were concerned for economic losses registered from 2016 to 2017. In 2018, Scientifics of two universities of the Mexicali city, where is located the industry analyzed at $20 \mathrm{kms}$, were begin a detailed analysis to reduce the costs and improve the productivity and quality of two farm products evaluated. These scientifics evaluated the principal flows distribution mentioned above, and considered that the flows analyzed, none were adequate to this type of industry. For this reason, was designed a new method to avoid errors with a fast and secure method to use as a new distribution flow (Bardaki, C. et al, 2012).

This originated an important improvement with the application of this novel G flow, with $85 \%$ of security of success to avoid extra costs. This evaluation was relevant in the industrial operations of the farm industry analyzed, and the new design of flow as G-form; apply activities of reception of materials, process of assembly of a product, sale in the center of fast distribution-manufacture-sale, and shipment of products to customers. With this design 
decreased deteriorated products and decreased the costs of the company evaluated. Based on the evaluation developed, the new method was designed and applied as a new model of distribution form in an industrial distribution center that also generated the sale of the product. The manufacturing process was used automatic systems to detect deteriorated products, and increase the velocity of the manufacturing processes, being a center of manufacture, distribution and sale. This industry is not a source of pollution, and damage to the environment, and not generates solid waste or hazardous waste (B.G. Lopez et al, 2007). The two products marketed by the evaluated industry were orange and serrano pepper, which exports to the United States, whose sales exceeded 100, 000 dollars per month in 2018 and 2019 and are estimated to exceed around 15\% for 2020, being a company of great tradition and with levels of economy that places it among the ten agricultural industries of the Mexican Republic. This was for the investigation developed and the $\mathrm{G}$ flow distribution with the adequate ergonomic methods applied. These two products are highly appreciated in restaurants and markets in the American Union. To develop the analyzes, sales evaluations were carried out by month from 2016 to 2019, indicating that from 2018 to 2019, when the study was carried out, improvements in sales and decrease in expenses were observed. This is observed in Table 1 with indices of processed sales, illustrating that the summer months were where the highest profits were generated in the company in the orange product due to high consumption, and the Chile serrano presented sales levels higher in the winter months. A possible deduction from the paragraph mentioned, was that in the summer the orange generated an adequate compensation of dehydration due to the high temperatures in the region of the state of Baja California in Mexico and California in the United States, which are desert areas in some regions of these two states. This was increased the saes of orange, and in addition, consuming food with Chile serrano generated a little body heat and with it a little comfort in the winter season, so sales increased in this period of the study.

Table 1. Sales of the agricultural products evaluated monthly (2016-2020*)

\begin{tabular}{|l|c|c|c|c|c|c|c|c|c|c|}
\hline $\begin{array}{l}\text { SALES, } \\
\text { dollar, \$ }\end{array}$ & \multicolumn{7}{|c|}{ Orange } & \multicolumn{5}{c|}{ Chile Serrano } \\
\hline MONTH & $\mathbf{2 0 1 6}$ & $\mathbf{2 0 1 7}$ & $\mathbf{2 0 1 8}$ & $\mathbf{2 0 1 9}$ & $\mathbf{2 0 2 0 *}$ & $\mathbf{2 0 1 6}$ & $\mathbf{2 0 1 7}$ & $\mathbf{2 0 1 8}$ & $\mathbf{2 0 1 9}$ & $\mathbf{2 0 2 0 *}$ \\
\hline January & 45,689 & 48,223 & 61,767 & 64,112 & 89,555 & 22,645 & 38,100 & 57,554 & 60,408 & 62,951 \\
\hline February & 42,553 & 45,063 & 58,606 & 60,930 & 86,385 & 20,265 & 38,610 & 57,853 & 60,096 & 62,639 \\
\hline March & 44,876 & 47,400 & 60,835 & 63,400 & 89,054 & 19,657 & 38,444 & 56,297 & 58,551 & 61,126 \\
\hline April & 46,843 & 49,377 & 62,942 & 65,507 & 89,931 & 17,345 & 34,110 & 51,879 & 54,133 & 56,676 \\
\hline May & 47,941 & 50,175 & 60,729 & 63,162 & 100,618 & 16,534 & 40,784 & 57,762 & 59,607 & 62,161 \\
\hline June & 52,137 & 54,591 & 67,156 & 69,591 & 93,925 & 15,892 & 33,326 & 47,670 & 49,493 & 49,578 \\
\hline July & 54,652 & 58,997 & 71,673 & 74,128 & 99,961 & 13,535 & 27,970 & 33,315 & 35,158 & 37,723 \\
\hline August & 57,813 & 60,046 & 72,592 & 75,249 & 77,892 & 12,892 & 23,457 & 23,461 & 25,313 & 27,856 \\
\hline
\end{tabular}




\begin{tabular}{|l|c|c|c|c|c|c|c|c|c|c|}
\hline September & 51,489 & 53,644 & 66,522 & 68,976 & 96,809 & 14,678 & 28,331 & 44,885 & 46,119 & 48,673 \\
\hline October & 47,946 & 50,401 & 64,947 & 67,492 & 93,925 & 16,867 & 30,522 & 53,067 & 54,301 & 56,866 \\
\hline November & 46,322 & 48,556 & 63,213 & 65,759 & 90,192 & 19,934 & 35,488 & 57,042 & 69,477 & 72,042 \\
\hline December & 44,189 & 46,523 & 61,088 & 63,653 & 86,086 & 21,834 & 38,499 & 65,076 & 66,330 & 68,895 \\
\hline
\end{tabular}

Table 1 illustrates, the sales indexes observed as in 2016 and 2017, the levels were less than 100, 000 dollars per month, indicating that the flow in the form of $\mathrm{G}$ had not been applied and neither the methods of ergonomics. From the beginning of the investigation in 2018, the G flowchart and ergonomics analysis were used to improve positions and avoid discomfort in the back parts of the body of workers, reflected in the increase in sales, shown in the table.

\section{Distribution flow in industries}

The use of distribution flow in diverse manufacturing processes and store of products fabricated, is an interesting step contemplated by the specialized personal and managers to organize the flow of products from the first step (reception of raw material), to the last step (shipping operations). This is part of the transformation of industrial logistics worldwide, where competitiveness is formulated to develop new innovations that lead to competiveness of companies (Fawcett, S. et al, 2011). The flow in an industry must be easy and without obstacles, to have the opportunity of increase the quality of products and reduce costs, to access a greater amount of customers.as large companies. The majorly of companies to grow in the industrial field, must develop innovations that support it to obtain a greater number of clients that lead it to transcend and stand out along with other worldwide recognized companies (Zhong, R. Y. et al, 2015).

Table 2. Analysis of distribution flow in industries of the northwest if Mexico (2019)

\begin{tabular}{|l|c|c|c|}
\hline Distribution Flow & Lineal & U-form & T-form \\
\hline \multirow{2}{*}{ Industry } & Period of use & Period of use & Period of use \\
\hline \multirow{2}{*}{ Biomedicaltural } & X & XX & XX \\
\cline { 2 - 4 } & From 2010 & Does not apply & Does not apply \\
\cline { 2 - 4 } & From 2005 & Does not apply & From 2012 \\
\hline Chemical & $\mathrm{X}$ & $\mathrm{XX}$ & $\mathrm{X}$ \\
\hline \multirow{2}{*}{ Electronic } & From 2014 & Does not apply & From 2016 \\
\hline Metallic & $\mathrm{X}$ & $\mathrm{X}$ & $\mathrm{X}$ \\
\cline { 2 - 5 } & From 2000 & From 2010 & From 2006 \\
\hline
\end{tabular}




\begin{tabular}{|c|c|c|c|}
\hline & From 2000 & From 2009 & Does not apply \\
\hline \multirow{2}{*}{$\begin{array}{l}\text { Plastic and } \\
\text { cardboard }\end{array}$} & $\mathrm{X}$ & $\mathrm{XX}$ & $\mathrm{XX}$ \\
\hline & From 2011 & Does not apply & Does not apply \\
\hline \multirow[t]{2}{*}{ Textile } & $\mathrm{X}$ & $X$ & $\mathrm{XX}$ \\
\hline & From 2007 & From 2013 & Does not apply \\
\hline
\end{tabular}

$\mathrm{X}$ Indicate the use of this type of distribution flow \& XX Indicate the not use of this type of distribution flow

Table 2 represents an analysis of the use of the three main flow distributions and the most important industries installed in the northwest of the Mexican Republic, with the cities of Ensenada and Tijuana as a marine area and that of Mexicali and its valley as a desert area. . The table indicates that the only industry that uses the three essential flows is the electronics industry. The linear flow is used in all industries in this region of Mexico, the $U$ type is used in the electronic, metallic and textile industries and the T type is used only in the chemical and electronic industry, where there are manufacturing cells by the various industrial processes.

In addition, it is illustrated since which annual period they have been used, being an average of all the 250 industries evaluated (INDEX, 2019) in the three mentioned cities. In this study were evaluated the principal distribution flows that are used in industries and warehouses with different forms of application and analyze the diverse operations to have the more optima organization. In this case was designed the new $\mathrm{G}$ flow, which was formed as a $\mathrm{G}$ figure, representing a new distribution flow, with an input and an output in a distribution center (Alftan, A., et al, 2015). This new method was analyzed with times and movements with a strict evaluation to avoid errors and decrease its close to cero errors and defects. Is very important evaluate the correctly flow of the products to save costs in the manufacturing and packing processes, to avoid storage unnecessary and not contemplated areas in some zones of any company, which generates extra spaces and additional cost to companies (Gregory G. et al, 2011).

\section{Industrial Operations}

In all industrial activity, the operations are based on globally standardized procedures such as ISO standards (ISO, 2015). That is why the design, organization and sale in the industry, should be considered important to form and achieve the rapid expansion of a company, when it is proposed to start the manufacture, distribution and sale of a product locally, nationally or globally.

Sometimes, some products, especially in the agricultural industry, as they do not have the adequate distribution flow within the company, can generate delays in the process flow and with it the agricultural products placed for long periods of time in some areas of companies and exposed to extreme climates such as in the Mexicali Valley, close to the $0{ }^{\circ} \mathrm{C}$ in the winter and higher than $40^{\circ} \mathrm{C}$ in the summer, cause them to deteriorate rapidly, generating economic losses. Examples of the aforementioned are shown in figure 1 with a deteriorated orange in June 2017 and in figure 2, with a deteriorated serrano chili in December 2017. As can be seen in Figures 1 and 2, the products deteriorated in a very short period of time, so the concern of the management and supervisory personnel required immediate solutions to prevent this situation from happening again. 


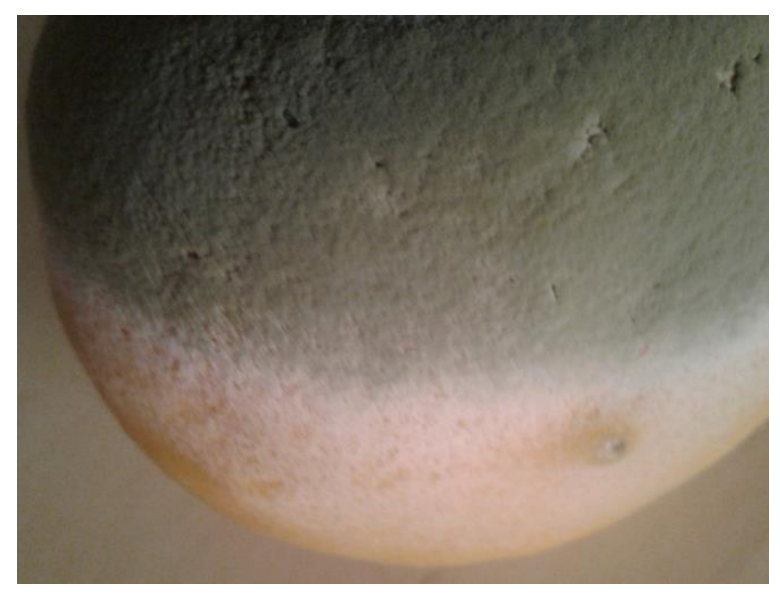

Fig.1. Orange deteriorated by high temperatures (at $40^{\circ} \mathrm{C}$ ) in June of 2017

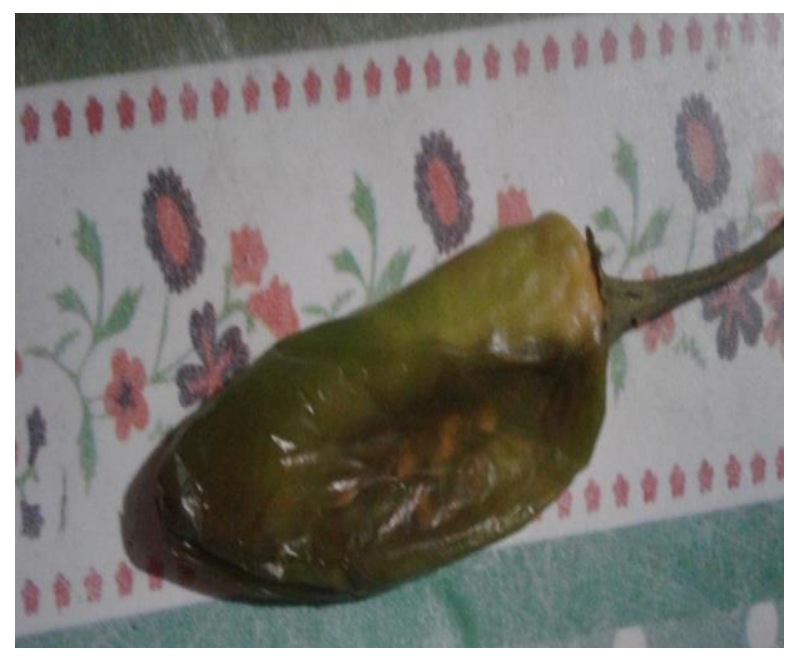

Fig.2. Chile serrano deteriorated by low temperatures (at $10^{\circ} \mathrm{C}$ ) in December of 2017)

The great challenge of achieving sales goals when starting a company at the micro level, is to be in the innovative field to be able to quickly climb the big leagues of the industrial approach. Due to this, new methods, techniques and innovative systems are constantly sought to optimize the manufacturing, distribution and sale processes of the manufactured products. With this, a microenterprise can quickly achieve its expansion to be considered first as a medium-sized company and later as a large company on a global level (Cai, J. et al, 2009). The flow chart of raw materials, sub-products and products in a company is of great importance for the appropriate transfers within and outside the companies. In addition, it is avoided to have areas of the industries with material for rework due to errors and deteriorated products called remnants. This also eliminates the great concerns of the management and supervision staff, having the products manufactured and packaged in the time determined in the customer delivery contracts. The main objective of this investigation was to transforms an agricultural industry to distribution and sales center. Logistics tools that are mentioned below were used (Kalpakjian S., 2014):

* Space organization system. It was used to properly organize the operations making the most of the spaces of a place to develop manufacturing activities.

* Route device. It was used in order to determine the most suitable route or flow to speed up operations and save time and movements. 
* Supply chain analysis. It was applied to know the materials and processes to be used in manufacturing processes, distribution centers and sales.

* Performance evaluation. It was used with the objective of evaluating performance in each manufacturing operation, distribution centers and sales.

* Continuous monitoring. It was applied to detect certain types of anomalies or errors that occur in the manufacturing processes, distribution centers and sales, and prevent them from being repeated or estimated so that they do not arise.

\section{Manufacturing process in the industry}

In all manufacturing activities, the six factors analyzed with the Ishikawa diagram, represented in figure 3 , and were evaluated in any type of manufacturing processes (Hadi-Vencheh, A. et al, 2011). Manufacturing processes are constantly evaluated to improve manufacturing steps, where it is sometimes contemplated to add operations and increase the speed of processes to achieve a greater reach with customers and the world market. There are different types of manufacturing processes where different types of flow distribution are applied, as well as ergonomic methods, to avoid the presence of errors and damage to the health of workers in any type of industry.

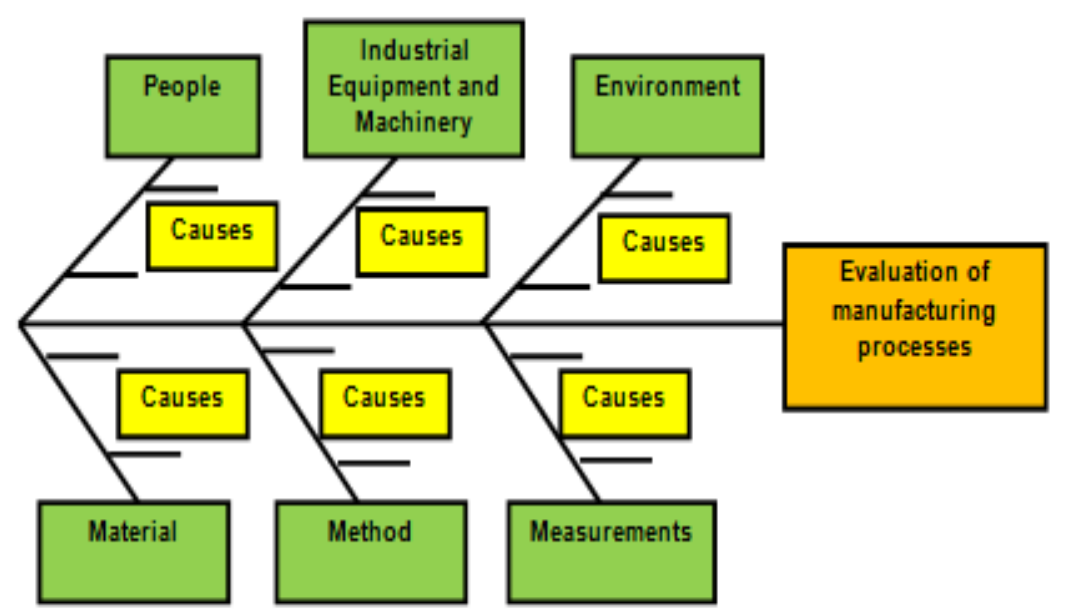

Fig.3. Factors evaluated with the Ishikawa diagram to industrial processes

\section{Flow processes}

There are mainly three types of continuous process flows, which are the linear type, U-shaped and T-shaped, with both linear and U-shaped being the most used in the manufacturing processes of the city of Mexicali, essentially in the agricultural industry of the Mexicali valley. In figure 4 is showed the linear type, where the flow is continuous, to very fast industrial operations.

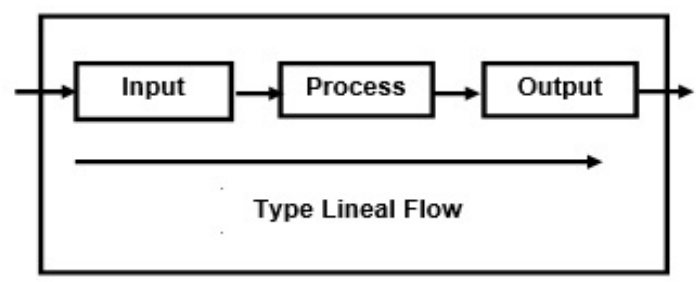

Fig.4. Layout of lineal flow 
In figure 5, is showed the $\mathrm{U}$ form flow, which is used to some specific industrial operations, where need a retro alimentation function, and finally figure 6 illustrate the $\mathrm{T}$ form flow, which is used with two or more industrial operations at same time (Wood, L. C. et al, 2017).

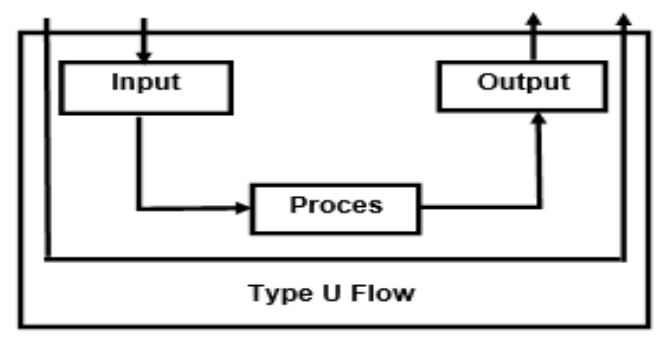

Fig.5. Layout of type U flow

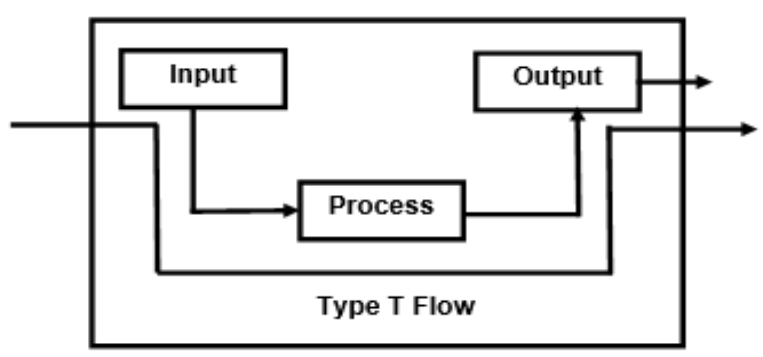

Fig.6. Layout of type T flow

\section{Methodology}

The investigation was developed to evaluate the flows of a industry as a small company, located in the Mexicali valley at the $20 \mathrm{kms}$ of the center of this city and was an innovation method as a new flow to save cost in a distribution center or warehouse (ISO, 2015). In addition, the innovation designed and developed with operations management processes was developed with experts. Also was made an analysis detailed of the ergonomic methods to evaluate the discomfort and pain of workers in each step of the manufacturing processes (ISO 11844-1, 2006).The investigation was made in five steps:

[1] An evaluation of the productivity.

[2] A distribution flow analysis.

[3] An evaluation of the environmental pollution.

[4] A design and test of a new model of distribution flow.

[5] An analysis of the use of ergonomic methods.

\section{Results}

The innovation of the new type G method, greatly supported a micro-company dedicated to the electronic industry with the manufacturing of electronic alarms to cars, to increase its sales, by joining the manufacturing processes and distribution and sales center. The increase in sales was $50 \%$, in a period of one year, being a very relevant information for the micro-company evaluated. 


\section{Ergonomic methods}

Manufacturing processes are evaluated with ergonomic methods, required to improve the postures of workers of any type of industry, who sometimes carry out activities without protective equipment, as well as the necessary tools. That is why in this investigation the pertinent evaluations were developed to developed the visual inspection and analysis operations with automated systems and with the packaging activities, with the postures necessary to avoid discomfort and body pain, essentially in the back, head, hands, neck, shoulders and spine. The detailed analysis of the application of the ergonomic methods required in the evaluated agricultural industry was very useful, due to the continuous presence of workers with discomfort who carried out the activities, sometimes with great discomfort, causing errors.

Table 3. Analysis of flow process and labor risks in industries of northwest of the Mexico (2019)

\begin{tabular}{|c|c|c|c|c|}
\hline $\begin{array}{l}\text { Manufacturing } \\
\text { processes }\end{array}$ & Linear flow & U-flow & T-flow & G-flow* \\
\hline Industries & Labor risks & Labor risks & Labor risks & Labor risks* \\
\hline Agricultural & $\begin{array}{c}\text { Could present } \\
\text { discomfort and pain in } \\
\text { back, head, hands, } \\
\text { neck, shoulders and } \\
\text { spine }\end{array}$ & Does not apply & Does not apply & $\begin{array}{c}\text { Could present } \\
\text { discomfort and } \\
\text { pain only in back }\end{array}$ \\
\hline Biomedical & $\begin{array}{c}\text { Could present } \\
\text { discomfort and pain in } \\
\text { back, head, neck and } \\
\text { spine }\end{array}$ & Does not apply & $\begin{array}{l}\text { Could present } \\
\text { discomfort and pain } \\
\text { in back and spine. }\end{array}$ & $\begin{array}{l}\text { Could present } \\
\text { discomfort and } \\
\text { pain }\end{array}$ \\
\hline Chemical & $\begin{array}{c}\text { IColud present } \\
\text { discomfort and pain in } \\
\text { back, neck, shoulders } \\
\text { and spine }\end{array}$ & Does not apply & $\begin{array}{c}\text { Could present } \\
\text { discomfort and pain } \\
\text { only in back. }\end{array}$ & $\begin{array}{c}\text { Could present } \\
\text { discomfort and } \\
\text { pain }\end{array}$ \\
\hline Electronic & $\begin{array}{c}\text { Cloud present } \\
\text { discomfort and pain in } \\
\text { back, head, hands, } \\
\text { neck, shoulders and } \\
\text { spine }\end{array}$ & $\begin{array}{l}\text { Could present } \\
\text { discomfort and pain } \\
\text { in back, head, } \\
\text { hands, neck and } \\
\text { spine }\end{array}$ & $\begin{array}{c}\text { Could present } \\
\text { discomfort and pain } \\
\text { in back, head and } \\
\text { spine. }\end{array}$ & $\begin{array}{c}\text { Could present } \\
\text { discomfort and } \\
\text { pain in back and } \\
\text { spine }\end{array}$ \\
\hline Metallic & $\begin{array}{c}\text { Could present } \\
\text { discomfort and pain in }\end{array}$ & $\begin{array}{c}\text { Could present } \\
\text { discomfort and pain }\end{array}$ & Does not apply & $\begin{array}{l}\text { Could present } \\
\text { discomfort and }\end{array}$ \\
\hline
\end{tabular}




\begin{tabular}{|c|c|c|c|c|}
\hline \multirow{2}{*}{$\begin{array}{c}\text { Plastic and } \\
\text { cardboard } \\
\text { shoulders and spine }\end{array}$} & $\begin{array}{c}\text { back, head, neck, } \\
\text { discomfort and pain in } \\
\text { back, neck, shoulders } \\
\text { and spine }\end{array}$ & $\begin{array}{c}\text { in back, head and } \\
\text { spine }\end{array}$ & Does not apply \\
Textile & $\begin{array}{r}\text { Could present } \\
\text { discomfort and pain in } \\
\text { back, head, hands and } \\
\text { spine }\end{array}$ & $\begin{array}{c}\text { Could present } \\
\text { discomfort and pain } \\
\text { in back, neck and } \\
\text { spine }\end{array}$ & Does not apply. & $\begin{array}{r}\text { Could present } \\
\text { discomfort and } \\
\text { pain only in back }\end{array}$ \\
\hline discomfort and \\
pain only in back
\end{tabular}

*Is an estimated analysis

The personnel specialized in analysis of occupational risks, elaborate the evaluations in each stage of the process and using specialized sensors to measure the angles of the appropriate positions, avoiding discomfort and pain in the workers of the evaluated industry. The NOM 035 was used in this analysis (NOM035, 2018).

\section{Economic factors}

In any type of industries, are a lot aspects to evaluate, being one of these, the economic factors to determine the form to elaborate the processes, if in sometimes is necessary make some improvements to implement new methods and technology.

Table 4. Productivity level (\%) with some flow processes

\begin{tabular}{|c|c|c|c|c|c|c|}
\hline P & \multicolumn{2}{|c|}{ ELF } & \multicolumn{2}{c|}{ ETUF } & \multicolumn{2}{c|}{ ETTF } \\
\cline { 2 - 7 } & PL & D & PL & D & PL & D \\
\hline D & 58 & 46 & 67 & 35 & 66 & 34 \\
\hline M & 59 & 41 & 68 & 38 & 68 & 39 \\
\hline S & 57 & 47 & 65 & 34 & 62 & 38 \\
\hline A & 59 & 49 & 68 & 37 & 68 & 36 \\
\hline
\end{tabular}

P. Periods; PL. Production Levels; D. Defects; ELF. Efficiency with Lineal Flow; ETUF. Efficiency with Type U Flow; ETTF. Efficiency Type T Flow. D. Daily; M. Monthly; S. Seasonally; A. Annually

Table 4 illustrates the productivity level, in base of manufactured products, with ranges of $57 \%$ to $59 \%$ of and defects from $41 \%$ to $49 \%$ in the lineal flow. In the type $\mathrm{U}$ flow, the ranges are from $65 \%$ to $68 \%$ to the productivity levels and from $34 \%$ to $38 \%$ to defects and finally the type T showed ranges from $62 \%$ to $68 \%$ to the productivity levels and $34 \%$ to $38 \%$ to defects, being the better to the product manufactured and evaluated in this investigation the type U flow. 


\section{Flow process analysis}

The flow process is very important in the manufacturing processes of any type of industry and was in this investigation in an agricultural industry located in the Mexicali valley in the northwest of Mexico, which is showed in table 5 .

Table 5. Flow process Efficiency (\%)

\begin{tabular}{|l|c|c|c|c|c|c|}
\hline \multirow{2}{*}{ P } & \multicolumn{2}{|c|}{ ELF } & \multicolumn{2}{c|}{ ETUF } & \multicolumn{2}{c|}{ ETTF } \\
\cline { 2 - 7 } & ET & CC & ET & CC & ET & CC \\
\hline D & 69 & 58 & 58 & 44 & 58 & 50 \\
\hline M & 66 & 56 & 55 & 43 & 62 & 53 \\
\hline S & 71 & 52 & 57 & 41 & 63 & 51 \\
\hline A & 67 & 55 & 53 & 45 & 61 & 50 \\
\hline
\end{tabular}

P. Periods; ET. Extra Time; CC. Customer's complaints; ELF. Efficiency with Lineal Flow; ETUF. Efficiency with Type U Flow; ETTF. Efficiency Type T Flow. D. Daily; M. Monthly; S. Seasonally; A. Annually

Table 6 represents the flow Efficiency, which was observed, with ranges from $66 \%$ to $71 \%$ of extra time and customer's complaints from 52\% to 58\% in the lineal flow. In the type U flow, the ranges are from 53\% to 58\% to extra time and from $41 \%$ to $45 \%$ to customers complaints and finally the type T showed ranges from $58 \%$ to $63 \%$ to extra time and from $50 \%$ to $53 \%$ to customers complaints, being the better to the product manufactured and evaluated in this investigation the type $\mathrm{U}$ flow.

\section{Environmental Pollution}

The levels of air pollution were determined in this step and were elaborated to know the indices of the climatic and environmental factors, which are showed in table 6.

Table 6. Evaluation of effect of climatic and pollution factors (\%)

\begin{tabular}{|l|c|c|c|c|c|c|}
\hline P & \multicolumn{2}{|c|}{ ELF } & \multicolumn{2}{c|}{ ETUF } & \multicolumn{2}{c|}{ ETTF } \\
\cline { 2 - 7 } & CF & AP & CF & AP & CF & AR \\
\hline D & 67 & 70 & 49 & 35 & 62 & 65 \\
\hline M & 64 & 62 & 54 & 43 & 59 & 62 \\
\hline S & 68 & 65 & 47 & 44 & 55 & 59 \\
\hline A & 67 & 66 & 48 & 46 & 56 & 64 \\
\hline
\end{tabular}

P. Periods; CF. Climatic Factors; AP. Air Pollutants; ELF. Efficiency with Lineal Flow; ETUF. Efficiency with Type U Flow; ETTF. Efficiency Type T Flow. D. Daily; M. Monthly; S. Seasonally; A. Annually 


\section{New flow process}

In this investigation was designed and made test to probe a new flow process as was called $\mathrm{G}$ form to new industrial operations and to improve the productivity and quality indices, which is showed in figure 4.

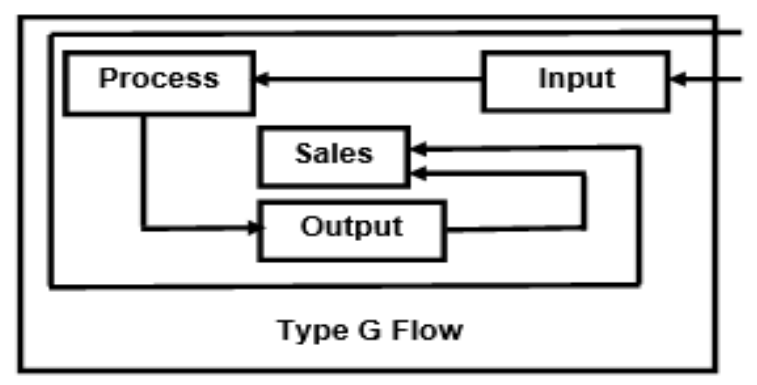

Fig.4. Layout of type G flow

In figure 4 is showed the innovation applied in the micro-company mentioned above, showing good results in the productivity levels, decreasing the defects, extra time and customer's complaints and the negative effect of atmospheric pollution as is showed in table 7 .

Table 7. Implementation of new flow process

\begin{tabular}{|l|c|c|c|c|c|c|}
\hline P & \multicolumn{2}{|c|}{ ETGF } & \multicolumn{2}{c|}{ ETGF } & \multicolumn{2}{c|}{ ETGF } \\
\cline { 2 - 7 } & PL & D & ET & CC & CF & AR \\
\hline D & 79 & 26 & 29 & 21 & 24 & 28 \\
\hline M & 70 & 23 & 27 & 25 & 22 & 26 \\
\hline S & 74 & 27 & 26 & 23 & 28 & 27 \\
\hline A & 77 & 22 & 29 & 26 & 26 & 25 \\
\hline
\end{tabular}

P. Periods; PL. Production Levels; D. Defects; ET. Extra Time; CC. Customer's complaints; CF. Climatic Factors;

AP. Air Pollutants; ELF. Efficiency Type G Flow D. Daily; M. Monthly; S. Seasonally; A. Annually

Table 7 shows numerical data of application of new $\mathrm{G}$ flow as innovation method, in base of manufactured products, with ranges of production levels from $70 \%$ to $79 \%$ and defects from $22 \%$ to $26 \%$. The rework has a negative effect in the costs of any industries, as is showed in this investigation about the ranges are from $26 \%$ to $29 \%$ of rework and not and not deliver the products on time to customers, being from $21 \%$ to $26 \%$ times that occurred in this scientific study elaborated. The climatic factors evaluated caused $22 \%$ to $28 \%$ of time added to the manufactured process, because it soiled the product and it was necessary to clean it constantly, and instead with the new design flow in $\mathrm{G}$, this was solved by $25 \%$, saving costs.

\section{Analysis of climate conditions and marketing}

The Mexicali Valley, which is part of the city of Mexicali, is located in a desert region, where the climatic conditions are adverse, with temperatures higher than $45^{\circ} \mathrm{C}$ and $\mathrm{RH}$ levels above $50 \%$ occurring in the summer 
season, and in the winter time temperatures close to $0 \mathrm{C}$ and $\mathrm{RH}$ percentages higher than $70 \%$, generating a rapid deterioration to the agricultural products evaluated in this investigation as observed in some figures in this text. In this investigation, it was observed that the quality of the products decreased by up to $35 \%$, generating large economic losses. The adverse weather conditions in this region of the Mexican Republic cause the products to deteriorate, generate economic losses and the marketing requires higher expenses because sometimes defective products are obtained to make other types of food products such as sauces with chilies in poor condition and juices with oranges in poor condition. A possible proposed solution to the new G-type flow model, in addition to automated systems that regulate cling conditions, such as cold room areas, at some stage of manufacturing, which will generate higher costs but will ensure increases in productivity and quality in this agricultural industry of the Mexicali Valley. Based on climate predictions of this agricultural region, projections of productivity, quality and sales were generated; with the firm objective of evaluating activities that helped to avoid the presence of defective products, deteriorated by the climate both in the summer time and in the winter, where the indexes of products damaged by the climate were presented before carrying out this investigation. Table 8 shows the percentage levels of productivity, where maximum and minimum production rates of $77 \%$ and $70 \%$ are shown, and quality of $68 \%$ and 65\%, derived from adverse climatic conditions, without using the flow of Process G. Once the process flow G was applied, productivity levels were improved and competitive with maximum and minimum production rates of $89 \%$ and $84 \%$, and quality of $88 \%$ and $81 \%$.

Table 8. Production and quality of agricultural products (\%) in summer and winter

\begin{tabular}{|l|c|c|c|c|}
\hline \multicolumn{1}{|c|}{ Products } & \multicolumn{2}{c|}{ ORANGE } & \multicolumn{2}{c|}{ CHIL E SERRANO } \\
\hline \multicolumn{1}{|c|}{ Productivity } & Summer & Winter & Summer & Winter \\
\hline Production, \%, without G flow & 76 & 70 & 77 & 73 \\
\hline Quality, \%, without G floe & 68 & 65 & 66 & 65 \\
\hline Production, \%, with G flow & 87 & 89 & 88 & 84 \\
\hline Quality, \%, with G flow & 84 & 85 & 82 & 81 \\
\hline
\end{tabular}

\section{Conclusions}

The use of the innovation as the type $\mathrm{G}$ flow using the logistic tools, improved the conditions of the manufacturing processes of the agricultural industry analyzed. This investigation will be a positive effect in the new transformation in the regional logistics that will be proposed in the industries of the northwest of the Mexican Republic. The type $\mathrm{G}$ flow have great advantages, because the productivity levels improved and the negative effects of the others parameters involved were decreased, being a flow reliable to the in6dustrial operations of any type of industries. The use of logistics tools in the industry is of great relevance and the application of ergonomic methods greatly supports the development of industrial process activities with excellent attitude, disposition and adequate ways to carry out manufacturing operations in various industries. In this investigation, analyzes of a new 
Asian Journal of Basic Science \& Research Volume 3, Issue 1, Pages 47-60, January-March 2021

G-shaped flowchart process were contemplated, which greatly supported the increase in the productivity and quality of agricultural products and with this improvement in the way of developing the activities of workers in the industrial processes of the evaluated company. The process is still being evaluated in order to elaborate some improvement that supports the elaborating of activities of the workers in an ergonomic way and with this, to be able to develop the activities applying the NOM 035 standard, which is in process in the Mexican Republic of being applied to all industries installed in this country, whether Mexican or foreign industries.

\section{Declarations}

\section{Source of Funding}

This research did not receive any specific grant from funding agencies in the public, commercial, or not-for-profit sectors.

\section{Competing Interests Statement}

The authors declare no competing financial, professional and personal interests.

\section{Ethical Approval}

All experiments were carried out as per institutional guidelines.

\section{Consent to participate}

Not Applicable

\section{Consent for publication}

We declare that we consented for the publication of this research work.

\section{Availability of data and material}

Authors are willing to share data and material according to the relevant needs.

\section{References}

1. Alftan, A., R. Kaipia, L. Loikkanen, K. Spens. (2015). “Centralized Grocery Supply Chain Planning: Improved Exception Management”; International J. of Physical Distribution \& Logistics Management; 45 (3): 237-259.

2. Bardaki, C., P. Kourouthanassis, and K. Pramatari. (2012). "Deploying RFID-Enabled Services in the Retail Supply Chain: Lessons Learned Toward the Internet of Things"; Information Systems Management Journal; Vol. 29 (3); pp. 233-245.

3. Chandra A., Chandna P., Deswal S., Kumar, R. (2009) "Ergonomics in the Office Environment: A Review", Proceedings of World Academy of Science: Engineering \& Technology, Vol 51 (1), pp 913-919. Conference Paper March 2009, Conference Enviro Energy 2009.

4. Carlos Raúl Navarro González, Yanet Villarreal González, Pedro Alberto Escárcega Zepeda, Ana Laura Sánchez Corona, Verónica Arredondo Robledo, Mildrend Ivett Montoya Reyes, Elizabeth Mora Moreno, Margarita Gil 
Samaniego Ramos, Olivia Yessenia Vargas Bernal (2020) "Analysis of Ergonomic Methods used to Prevent Negative Effect in the Health of Workers in a Metallic Industry in Mexicali, Mexico", Mediterranean Journal of Basic and Applied Sciences (MJBAS) Volume 4, Issue 3, Pages 33-41, July-September 2020.

5. Fawcett, S. E., C. Wallin, C. Allred, A. M. Fawcett, and G. M. Magnan. (2011). "Information Technology as an Enabler of Supply Chain Collaboration: A Dynamic-Capabilities Perspective"; Journal of Supply Chain Management; Vol. 47 (1); pp. 38-59.

6. Gregory G., Fontanent A. (2011). "The evaluations of manufacturing processes with the FMEA method": Science applied to Industry Journal; Vol. 3 (1); pp. 79 - 92.

7. Harshal T. (2017) “Historical Milestones of Ergonomics: From Ancient Human to Modern Human”, Journal of Ergonomics, Vol 7 (4), pp 65-78.

8. Hadi-Vencheh, A., M. Niazi-Motlagh. (2011). "An Improved Voting Analytic Hierarchy Process-data Envelopment Analysis Methodology for Supplier Selection"; International Journal of Computer Integrated Manufacturing; Vol. 24; pp. 189-197.

9. INDEX-Baja Californiai (2019). Reporte de empresas maquiladoras de Baja California.

10 ISO 9001:2015. (2015). *Quality Management Systems — Requirements.

11. ISO 11844-1. (2006). Corrosion of metals and alloys - Classification of low corrosivity of indoor atmospheresDetermination and estimation of indoor corrosivity. ISO, Geneva.

12. Kalpakjian S. (2014). 'Manufacturing engineering and technology”; Prentice Hall Ed., Book; 2nd. Ed.; pp. 89 13. Loos M., Merino E., Taboada C. (2016) "Mapping the state of the art of ergonomics within logistics", Scientometrics Journal, Vol 109, PP 85-101. 